\title{
Gender dan GayaKepemimpinan Perempuan Di Jabatan Publik: Studi Fenomenologi Pelaksanaan Syariat Islam di Aceh
}

\author{
Rahma Hidayati $^{1}$ \\ (Prodi Ilmu Komunikasi, UniversitasTeuku Umar) \\ rahmahidayati@utu.ac.id \\ Nellis Mardhiah ${ }^{2}$ \\ (Prodi Administrasi Negara, UniversitasTeuku Umar) \\ nellismardhiah@utu.ac.id
}

\begin{abstract}
Abstrak
Acehnese women are known to be very unique, have distinctive moralist leadership styles and high fighting spirit with the nickname "Cut NyakDhien". These characteristics are inherent in their identity and able to integrate for the achievement of organizational goals. The objective of this study is the style of Acehnese women's leadership in public position. This study uses a qualitative method with a phenomenological approach that seeks to interpret events related to the situation holistically with empirical social reality. The results of this study are the presence of Acehnese women in the organization is very significant in the representation of organizational decision making. Representation also has a strategic function as communicative internalization that is firm in instilling the values of gender equality in every activity and the pattern of relations between the structure, role and function of a system. The moralist leadership pattern in organizational development in carrying out social and cultural duties and responsibilities can be done through a process of negotiation and mutual cooperation, where all forms of differences can find harmony with the distribution of roles and functions that are balanced from position and full commitment to Acehnese women in the Islamic law .
\end{abstract}

Keywords: Gender, Leadership Style, Public Position, Islamic Shari'a 


\section{PENDAHULUAN}

Perilaku sosial yang sangat sering diperbincangkan dalam media sosial pada umumnya di Indonesia tentang kekerasan terhadap perempuan. Keadaan demikian sering mengalami dari segi ketidakadilan gender melalui marginalisasi. Hal ini menjadi saling tarik ulur antara peran domestik dan peran publik perempuan dalam meninternalisasi dirinya sebagai kepemimpinan sebuah organisasi. Proses marginalisasi yang mengakibatkan kemiskinan banyak sekali terjadi dalam masyarakat dan negara yang menimpa kaum laki-laki dan perempuan, misalnya konflik, bencana alam, serta proses ekploitasipun dapat mengakibatkan pola opresi keberadaan perempuan yang termarginalisasi dalam kehidupan sehari-hari.

Komitmen pemerintah indonesia melalui Kementerian Negara Pemberdayaan perempuan untuk mewujudkan kesetaraan dan keadilan gender juga sangat tinggi. Namun, dalam kenyataannya ketimpangan gender dalam segala aspek kehidupan tetap terjadi, sehingga sangat perlu dilakukan identifikasi terhadap berbagai faktor yang menjadi penyebabnya agar diperoleh solusi yang tepat sesuai dengan persoalannya. Wacana tentang isu gender sudah menjadi isu yang mendunia. Pada umumnya isu gender yang paling sering dibahas adalah masalah status dan kedudukan perempuan di masyarakat yang masih dinilai subordinal atau marginal. Persoalan ketidaksetaraan dan ketidakadilan gender bukanlah persoalan sederhana dan berdimensi lokal, namun persoalan ini ditemui di seluruh belahan dunia, serta berkaitan erat dengan segala sendi kehidupan manusia. Maka tidaklah mengherankan jika boleh dikatakan perjuangan para pemerhati masalah perempuan, untuk meningkatkan kesetaraan dan keadilan gender yang sudah sekian lama seolah-olah jalan di tempat, atau paling sedikit hasil yang dicapai belum sesuai dengan harapan(KemNeg PP dan BPS, 2006).

Dilihat dari sejarah perhatian dunia secara formal mengenai persamaan antara laki-laki dan perempuan yang telah diklarasikan olehThe Universal Declaration of Human Rights (Deklarasi Universal Hak Asasi Manusia), oleh Perserikatan BangsaBangsa (PBB), dan tahun 1976 dilengkapi menjadi The International Bill of Human Rights (Pernyataan Hak Asasi Manusia). Presiden Amerika pada saat itu Jimmy Carter menyatakan bahwa Piagam PBB berbicara tentang keyakinan pada hak asasi manusia yang fundamental, pada martabat dan penghargaan manusia, pada persamaan hak lakilaki dan perempuan dan bangsa-bangsa besar dan kecil (Heraty, 1999). Pernyataan tersebut secara implisit mengemukakan bahwa ada ketidaksamaan hak antara laki-laki dan perempuan didunia ini, sehingga perlu dibuat dalam sebuah pernyataan agar negara, maupun masyarakat, mengindahkan persamaan hak tersebut sebagai sebuah hak asasi manusia. Gerakan feminis di negara Amerika Serikat sudah dimulai jauh sebelum masa itu, misalnya seorang Feminis Amerika yang bernama Elizabeth Cady Stanton (18151902) yang memprakarsai konvensi hak-hak perempuan tahun 1848 di Seneca Falls dan memperjuangkan hak suara kaum perempuan di negara itu (Hadiz, 1998), namun baru seratus tahun kemudian PBB secara resmi menyampaikan deklarasi tentang hak asasi 
manusia termasuk hak perempuan dan laki-laki. Hal ini juga sebuah pertanda bahwa demikian tidak mudah untuk mencapai kesetaraan dan keadilan gender, baik di negara maju maupun di negara berkembang seperti Indonesia

Pandangan gender juga mengasumsikan bahwa perempuan irrasional atau emosional sehingga perempuan tidak bisa tampil menjadi pemimpin, namun pada kenyataannya memerlukan pertimbangan kepada perempuan dalam internalisasinya sebagai pemimpin dalam organisasi. Maka dengan demikian dalam realita sosial persoalan demikian berakibat kepada pemahaman laki-laki sangat ironis yang menempatkan perempuan pada posisi yang tidak penting ataupun dinomor duakan, serta secara umum steriotipe terhadap perempuan adalah pelabelan atau penandaan terhadap suatu kelompok tertentu yang mana pandangan tersebut bersumber dari gender.

Perempuan Aceh dalam perspektif perjuangan sejarah dapat terlukiskan dalam perjuangan di wilayah Aceh. Jati diri perempuan Aceh dapat ditunjukkan dalam sanubari pahwalan Cut Nyak Dhien dalam memperjuangkan ketahanan wilayah Aceh dalam merebutkan kemerdekaan dari para penjajahan Belanda. Namun oleh karena itu, ketika medndiskusikan kedudukan perempuan Aceh sangat sulit dipahami dalam jati diri mereka yang tampak telah mendomisili wilayah publik. Menurut Ahmad (2015) dalam hasil penelitian nya menyebutkan bahwa kiprah perempuan Aceh yang mendomisili wilayah publik sebagai pola rekayasa sosial di Aceh, dimana perempuan Aceh secara dinamis akan menghadapi era modernisasi yang mendominasi dalam kedudukan peranan diwilayah publik adanya kesamaan peran yang dimainkan sebagai laki-laki, akan tetapi memerlukan penjelasan yang tegas dengan standar etika dalam rekayasa sosial di lingkungan masyarakat Aceh secara khusus nya.

Studi perempuan Aceh menurut historis sejarah menunjukkan bahwa sejarah perjuangan masa era Cut Nyak dhien dan Cut Nyak Mutia yang telah terbukti sebagai pemimpin peperangan dalam merebutkan kemerdekan bagi masyarakat Aceh. Hal demikian telah menunjukkan ciri kepemimpinan perempuan dalam tataran publik, akan tetapi masih saja diskriminatif karena asumsi keberadaan perempuan sangat lemah dalam menjalankan kebijakan publik. Demikian pula,akan tetapi Ahmad (2015) juga menambahkan kiprah perempuan Aceh dari segi tingkat ketahanan diri sebagai singel parent menunjukkan lebih mampu membawa diri dalam eksisitensi publik sebagai perempuan Aceh di perinkat desa dan kota serta di era modernisasi dapat menunjukkan eksisitensinya dari segi kualitas dan kuantitas yang telah merubahkan pola sosial budaya bagi perempuan Aceh secara dinamis yang sangat perlu dibahaskan secara khsusus untuk dapat menjawab persoalan-persoalan perempuan dalam internalisasi dirinya harus menduduki jabatan publik.

Internalisasi kepemimpinan bagi perempuan seringkali berasumsi bahagian dari pola pikir dan pegembangan nya dari sudut pandangan politik, artinya peranan perempuan yang telah diinternalisasikan dalam jabatan publik sebagai contoh; menjadi keterwakilan perempuan sebagai anggota legislatif. Hal ini menjadikan sebagai pondasi 
pilar perempuan diletakkan sebagai agen perubahan dalam perspektif pembangunan bangsa. Namun dengan demikian hal nya Jeumpa (2016) menyatakan bahwa peran perempuan dalam keterwakilan sebagai internalisasi politik harus memiliki berkarakter dalam jiwa kepemimpinan diberikan melalui pendidikan politik demi untuk mencapai originalitas dalam pengembangan pola pikir perempuan yang memiliki kepekaan dan halus, lembut dalam menjalankan kebijakan yang bermanfaat bagi masyarakat. Maka oleh karena itu, keterlibatan perempuan dalam menjalankan peranannya di organisasi publik menjadikan pertimbangan khusus bagi pemerintah indonesia untuk mencapai pembangunan bangsa secara dinamis.

Keterlibatan perempuan dalam menjalankan organisasi publik hanya dipersepsikan sebagai figur ekpresif dan intrumental, dimana figur ini menunjukkan peran perempuan sebagai aktor publik dalam perilaku sosial kodrat perempuan sejatinya bagi keluarga (Puspitawati, 2010). Namun dengan demikian peran kepemimpinan perempuan dapat ditunjukkan dengan baik dengan metode terbukan dalam penyelesaian masalah organisasi, dimana pola kepemimpinan laki-laki dalam sebuah organisasi dapat ditunjukkan cenderung tertutup dalam penyelesaian masalah organisasi, Hal ini sangat penting untuk dikembangkan dalam sebuah organisasi publik sebagai kinerja yang dapat ditunjukan oleh pemimpin tersebut yang menjadi pondasi kuat apakah seorang perempuan mampu atau tidak menjadi sejajar dengan kaum laki-laki dari segi kepemimpinannya (Ditaria, 2016). Keadilan dan ksetraan gender yang menarik bagi perempuan Aceh, memiliki karakteristik yang tegas dan khas yang dipengaruhi pada masa konflik dan bencana stunami. Justru sebalik, figur ekpresif dan instrumental menjadi kekuatan bagi nilai perjuangan perempuan Aceh dalam meningkatkan ketahanan diri nya terutama dihadapan publik harus membina organisasi. Maka oleh

karena itu, penelitian ini bertujuan ingin memahami secara mendalam tentang internalisasi perempuan Aceh dalam perspektif gender yang telah difungsikan dalam substansi organisasi pemerintah maupun swasta yang berorientasi sebagai pemicu gagasan pembangunan.

\section{TINJAUAN PUSTAKA}

\section{Definisi Gender}

Gender mempunyai arti perbedaan peran laki-laki dan perempuan dari sisi tanggungjawab dan fungsi dan ruang tempat dimana manusia bisa beraktivitas. Gender adalah suatu konsep yang merunjuk pada sistem peranan dan hubungannya antar perempuan dan lelaki yang tidak ditentukan oleh perbedaan biologi, akan tetapi ditentukan oleh lingkungan sosial, politik, dan ekonomi (Vitalaya S Hubies, 2010). Istilah gender pertama kali diperkenalkan oleh Robert Stoller untuk memisahkan pencirian manusia yang didasarkan pada pendefinisian bersifat sosial budaya yang berasal ciri fisik biologis. Dalam ilmu sosial orang yang juga sangat berjasa dalam 
mengembangkan istilah dan pengertian gender ini adalah Ann Oakley. Sebagaimana Stoller. Oakley mengartikan gender sebagai konstruksi sosial atau atribut yang dikenakan pada manusia yang dibangun oleh kebudayaan manusia (Nugroho, 2011). Analisis gender adalah suatu metode untuk mendeteksi kesenjangan gender melalui penyediaan data dan fakta serta informasi tentang gender yaitu data yang terpilah antara laki-laki dan perempuan dalam aspek akses, peran, kontrol dan manfaat. Dengan demikian analisis gender adalah proses analisis data dan informasi secara sistematis tentang laki-laki dan perempuan untuk mengidentifikasi dan mengungkapkan kedudukan, fungsi, peran dan tanggung jawab laki-laki dan perempuan, serta faktor-faktor yang mempengaruhi. Syarat utama terlaksananya analisis gender adalah tersedianya data terpilah berdasarkan jenis kelamin. Data terpilah adalah nilai dari variabel variabel yang sudah terpilah antara laki-laki dan perempuan berdasarkan topik bahasan/hal-hal yang menjadi perhatian. Data terdiri atas data kuantitatif dan kualitatif.

Kesetaraan gender adalah kedudukan bagi perempuan dan laki-laki yang menunjukkan status dan kondisi yang sama untuk melaksanakan hak azasinya secara penuh dan berpotensi dalam menyumbangkannya dalam pembangunan, dengan demikian kesetaraan gender adalah penilaian dan kedudukan yang sama oleh masyarakat terhadap persamaan dan perbedaan perempuan dan laki-laki dari berbagai peran yang lakukan (KMNPP RI, 2001).

Konsep gender yakni sifat dan karakter yang melekat pada kaum laki-laki maupun perempuan yang dikonstruksi secara sosial maupun secara kultural (Fakih, 1996). Hal ini keberadaan dan karakteristik perempuan itu dikenal lemah lembut, cantik, emosional, atau keibuan. Sementara laki-laki dianggap kuat, rasional, jantan dan perkasa. Sejarah perbedaan gender antara jenis laki-laki dan perempuan terjadi melalui proses yang sangat panjang dan terbentuknya konsep gender dibentuk, diasosiasikan, diperkuat bahkan dapat dipengaruhi secara sosial dan budaya. Konsep ini juga dapat menggambarkan gender kemudian melahirkan marginalisasi yang mengakibatkan kemiskinan, Beberapa studi yang dilakukan dalam rangka membahas program pembangunan pemerintah yang menjadi penyebab kemiskinan. Pola legalitas yang telah dibentuk negara dan laki-laki tersebut ialah pandangan gender yang ternyata menimbulkan kesenjangan dan ketidakadilan terhadap perempuan. Pandangan semacam ini yang menempatkan kaum perempuan sebagai kaum yang atau emosional sehingga perempuan tidak bisa memimpin yang kemudian berakibat munculnya sikap yang menempatkan perempuan pada posisi yang tidak penting. Gender tersebut terjadi dalam segala macam bentuk yang berbeda dari tempat ke tempat dan dari waktu ke waktu. Selanjutnya terjadi ketidakadilan terhadap perempuan yang menunjukkan sebagai kaum pinggiran dan lemah tidak mampu menggunakan logika untuk memandang dunia.

Sistem Gender, Stanton menyatakan bahwa perempuan merupakan makhluk yang inferior diciptakan dari tulang rusuk laki-laki yang tunduk pada laki-laki 
(Rosmerie, 2008). Sistem gender dapat menggambarkan keberadaan perempuan yang aktif dalam gerakan perempuan tidak mampu untuk melihat realitas yang sebenarnya. Perempuantidak rela berada dalam jalur filosofis feminism akan tetapi sebagai politik praktis. Menurut Alison Jaggar dan Paula Rothenberg klaim sistem gender dapat dikatogorikan sebagai berikut: a. secara historis, perempuan merupakan kelompok teropresi yang pertama. b. Opresi terhadap perempuan adalah paling menyebar dan ada di dalam setiap masyarakat yang diketahui. c. Opresi terhadap perempuan adalah yang terdalam, yang berarti sulit dihapuskan atau dihilangkan dalam perubahan sosial. $d$. Opresi terhadap perempuan menyebabkan penderitaan yang paling buruk korbannya, baik secara kualitatif maupun kuantitatif.

\section{Gender dalam Perspektif Syariat Islam di Aceh}

Keberadaa gender dalam konteks pemberlakuan syariat Islam di Aceh terdapat beberapa persoalan, di antaranya adalah persoalan posisi syariat yang diformulasikan hanya kebutuhan masa rezim yang sedang untuk membangun citra pepolitikan. Hal ini dilakukan sebagai bentuk 'kompromi politik' antara rezim penguasa dengan masyarakat pendukungnya, kendatipun demikian terjadinya bagi kedudukan sebagai perempuan Aceh sebagai identitas dalam pemberlakuan syariat Islam Soviana (2016). Menurut penelitian nya pula telah menjustifikasikan bahwa qanunsyariat Islam merupakan identitas perempuan terkendala oleh kebijakan yang dibuat oleh pemerintahan Aceh. Masalah syariat Islam yang debatable menjadi persoalan serius di pihak lain disebabkan banyak pemahaman tentang syariat Islam itu sendiri apakah harus dilegal-formalkan ataukah syariat itu adalah etika untuk bermasyarakat.

Sementara wahyuningron (2002) menyatakan bahwa peranan perempuan dalam jabatan struktural yang dilakukan oleh masyarakat terhadap kelompok tertentu dalam bentuk norma-norma, simbol simbol, dan perlakuan lain yang diberlakukan dalam masyarakat tersebut. Dengan demikian merupakan akibat dari proses sehari-hari masyarakat, melalui interaksi sosial, media, stereotip budaya, birokrasi, mekanisme pasar, dan sebagainya. Dalam pengertian ini, opresi umumnya tidak dapat dikenali oleh masyarakat yang melakukannya karena praktik opresi peranan perempuan Acehmerupakan nilai-nilai yang dianut.Kemudian menurut penyataan saiful (2016)perspektif gender dalam dan pandangan ulama serta cendikiawan muslim berperspektif gender dalam formulisasi syariat Islam adalah pemerintah menjelaskan parameternya pembentukan qanun yaitu, pancasila sebagai dasar negara dijadikan parameter kesetaraan gender, disamping beberapa ketentuan lain berupa undangundang, perjanjian dan konvensi internasional yang melindungi hak-hak perempuan. Pemahaman terhadap hakikat keberadaan teks Al-Qur'an dan hadist tentang nilai-nilai keislaman perlu mendapat kajian khusus dan mendalam guna menemukan ruh syariah (nilai filosofis) dari suatu ketentuan hukum dalam upaya formalisasi syariat Islam berperspektif gender dalam aspek syariat Islam Di Aceh. Penyataan sari (2016) dalam 
penelitiannya menjelaskan bahwa keterlibatan perempuan dalam politik di Aceh harus tetap menjaga identitasnya sebagai muslimah bahkan ada juga ulama yang menolak perempuan terlibat dalam bidang politik karena akan menghadapi banyak kendala dan perempuan dianggap kurang tegas dalam memimpin. Serta adanya perbedaan penafsiran seperti penafsiran ayat Alquran dan Hadis, juga ada sebagian Ulama tidak terlalu paham tentang politik dan selain itu faktor pengaruh tingkat keilmuan dan pengetahuan. Unsur keterlibtan perempuan dalam perencanaan pembangunan di Aceh masih dinilai sangat kurang dibandingkan kaum laki-laki yang lebih mendominasi sehingga sering terjadinya bias genderdalam internalisasi kedudukan perempuan (Khalil, 2013). Demikian pula Hulwati (2015) Kritik terhadap bias gender dalam perspektif fiqh merupakan ungkapan emosional yang menggeneralisasi nya, padahal klaim bias gender hanya terjadi keberadaan perempuan yang bukan muhrimnya dalam kedudukan di organisasi. Pendapat bias gender dalam fiqh merupakan pendapat yang memandang fiqh sesuatu yang final, dalam pemetaan hukum Islam, fiqh merupakan prodak ijtihad yang dinamis dengan teori evolusi kontinuitas. Fiqh dapat berkembang dan melakukan perubahan berdasarkan zaman, waktu, tempat, sosiologis, budaya dan perkembangan ilmu pengetahuan tekhnologi.

\section{Gaya Kepemimpinan}

Gaya kepemimpinan mencakup tentang bagaimana seseorang bertindak dalam konteks organisasi tersebut, maka cara termudah untuk membahas berbagai jenis gaya ialah dengan menggambarkan jenis organisasi atau situasi yang dihasilkan oleh atau yang cocok bagi satu

Gaya tertentu (Miftah Thoha, 1995). Gaya kepemimpinan yang efektif mencakup tentang bagaimana seseorang bertindak dalam konteks organisasi, maka cara termudah untuk membahas berbagai jenis gaya ialah dengan menggambarkan jenis organisasi atau situasi yang dihasilkan oleh atau yang cocok bagi satu gaya tertentu. Gaya kepemimpinan yang mana yang sebaiknya dijalankan oleh seorang pemimpin terhadap organisasinya sangat tergantung pada kondisi anggota organisasi itu sendiri. Dengan mengetahui kondisi nyata anggota, seorang pemimpin dapat memilih model kepemimpinan yang tepat. Tidak menutup kemungkinan seorang pemimpin menerapkan gaya yang berbeda dan divisi berbeda pula. Menurut Robert Albanese, David D. Van Fleet (1994) dalam teori nya menjelaskanGaya kepemimpinan yang mana yang sebaiknya dijalankan oleh seorang pemimpin terhadap organisasinya sangat tergantung pada kondisi anggota organisasi itu sendiri. Pada dasarnya tiap gaya kepemimpinan hanya cocok untuk kondisi tertentu saja. Dengan mengetahui kondisi nyata anggota, seorang pemimpin dapat memilih model kepemimpinan yang tepat. Tidak menutup kemungkinan seorang pemimpin menerapkan gaya yang berbeda untuk divisi atau seksi yang berbeda. Gaya setiap pemimpin tentunya berbeda-beda, demikian juga dengan 
para pengikutnya. Ini merupakan cara lain untuk mengatakan bahwa situasi-situasi tertentu menuntut satu gaya kepemimpinan tertentu, sedangkan situasi lainnya menuntut gaya yang lain pula. Gaya kepemimpinan yang dijalankan oleh seseorang berbeda satu sama lain.

\section{Teori Feminisme}

Menurut Ritzer, (2012) Feminisme merupakan faham untuk menyadarkan posisi perempuan yang rendah dalam masyarakat, dan keinginan memperbaiki atau mengubah keadaan tersebut. Posisi perempuan selama ini di masyarakat selalu berada di bawah atau di belakang laki-laki. Posisi yang sangat tidak menguntungkan. Bagi perempuan untuk mengembangkan dirinya. Feminisme menjadi bergerak bagi perubahan posisi perempuan di masyarakat.Berikut ini ada beberapa pengertian feminisme menurut para ahli yaitu:

i. Maggi Humin : Sebuah ideologi pembebasan perempuan karena yang melekat dalam semua pendekatannya adalah keyakinan bahwa perempuan mengalamiketidakadilan karena jenis kelamin;

ii. Mansour Fakih : Gerakan dan kesadaran yg berangkat dari asumsi bahwa kaum perempuan pada dasarnya ditindas dan dieksploitasi, serta usaha Untuk mengakhiri penindasan \& eksploitasi tersebut;

iii. Ideologi politik : Sekumpulan gagasan yang selalu berubah-ubah, gagasan ini merupakan tanggapan yang digerakan oleh ketidakadilan dalam diri perempuan yang tersinggung karena memperioritaskan hak-hak tertentu untuk kaum lakilaki.

Feminis sosialis menekankan pada aspek gender dan ekonomis dalam penindasan atas kaum perempuan. Perempuan dapat dilihat sebagai penghuni kelas ekonomi dalam pandangan Marx dan "kelas seks", sebagaimana disebut oleh Shulamith Firestone. Artinya, perempuan menampilkan pelayanan berharga bagi kapitalisme baik sebagai pekerja maupun istri yang tidak menerima upah atas kerja domestik perempuan. Dalam feminis sosialis perempuan tereksploitasi oleh dua hal yaitu sistem patriarkhi dan kapitalis.

\section{METODELOGI PENELITIAN}

Metode penelitian yang digunakan adalah kualitatif dengan tinjauan studi kepustakaan (Library Research). Data-data dan informasi yang diperoleh dari lapangan diinterpretasikan melalui analisa deskriptif. yang berasaskan pada penelitian dengan gender. Pemilihan subjek dilakukan dengan menggunakan teknik purposive sampling, dengan kriteria subjek sebagai berikut: 1) Perempuan, bersuku Aceh yang bagian dari korban konflik dan bencana stunami serta kelompok Perempuan Aceh pada umumnya sebagai pimpinan publik dari kalangan pemerintah, akademisi maupun pihak swasta merupakan kaum yang tersubordinasikan kedudukannya secara adat istiadat dalam 
budaya 2) Bertempat tinggal di Aceh, sehingga dapat mengetahui, memahami dan menjalankan bagaimana seluk beluk adat istiadat Aceh dalam metode kepemimpinan menjalankan organisasi. 3) Metode pengumpulan data yang digunakan dalam penelitian ini adalah wawancara mendalam dan observasi semi-partisipan.

\section{HASIL DAN PEMBAHASAN}

Internalisasi gender dan gaya kepemimpinan sangat dipengaruhi dengan pola komunikasi perempuan dalam jabatan publik. Gaya kepemimpinan ini bagi perempuan Aceh sangat unik dan khas dengan semangat juang yang tinggi, serta menginternalisasi diri sebagai pemimpin dalam jabatan publik. Untuk itu, gaya kepemimpinan yang dimiliki oleh perempuan Aceh di jabatan publik adalah gaya kepemimpinan moralis yang diterapkan oleh perempuan Aceh dalam perpektif syariat Islam. Gaya kepemimpinan perempuan Aceh secara moralis dapat di uraikan sebagai berikut:

\section{Gender dan ideologi Normatif}

Gaya kepemimpinan ini yang diterapkan sebagai perempuan Aceh dalam pengembangan organisasidengan mengutamakan asas normatif sesuai dengan kode etik syariat Islam. Dalam konteks ini merupakan nilai-nilai kekuatan yang kebijakan syariat Islam yang telah di jalankan oleh perempuan Aceh. Salah satu nya ketetapan perundangan-undangan tentang syiar Islam yaitu,Qanun Nomor 12 Tahun 2003 tentang minuman Khamar, Qanun Nomor 14 Tahun 2003 Tentang Khalwat serta Qanun Nomor 6 Tahun 2014 tentang Jinayah. Justifikasi qanun ini tersebut telah termajinalisasi keberadaan perempuandalam mengatasi masalah organisasi. Hal ini dianggap keberadaan perempuan telah dibatasi dengan asas normatif. Namun ideologi normatif bagi perempuan menjadi ciri khas dalam mengatasi masalah organisasi mendapatkan sandaran dan kedudukan perempuan di level kehormatan yang sangat tinggi berdasarkan Al-Quran dan Hadist. Perempuan Aceh telah membuktikan dari sejarah perjuangan bahawa memiliki kematangan dan keseimbangan emosional menjadi dalam kedudukan di jabatan publik, serta keberadaaan perempuan di Aceh sebagai pemimpin publik sudah dapat dibuktikan dalam sejarah.

\section{Gender dan Jabatan Publik}

Sejarah Acehtelah mencatat bahwakeberadaan perempuan dalam jabatan publik, dari sejarah nama perempuan yang menonjol di masa lalu dalam hal kepemimpinan dan perlawanan. Jauh sebelum berdirinya Kerajaan Aceh Darussalam, kepemimpinan kerajaan di Aceh pernah dipegang oleh perempuan, yakni Puteri Lindung Bulan yang memerintah Kerajaan Benua/ Teuming (1333-1398) dan Ratu Nihrasiyah Rawangsa Khadiyu yang memimpin Kerajaan Islam Samudra/Pase (1400-1428) (Hasjmy 1976:24-25). Begitu pula, peran kepemimpinan perempuan dalam jabatan publik tidak lepas dari statusnya sebagai identitas seksual perempuan. Artinya, perempuan menjadi 
pemimpin sudah sangat dinamis di Aceh. Namun ketika secara realita sosial, perempuan keterwakilan dijabatan publik secara umum di Aceh berada dalam posisi subordinat terhadap laki-laki. Hal ini karena peran dan kedudukan perempuan dalam masyarakat Aceh merupakan konstruksi sosial yang terbangun atas dasar pemahaman masyarakat atas nilai-nilai kultural dan interpretasi agama Islam. Nilai-kultural dan interpretasi syariat Islam. Dalam hal ini, perempuan dibatasi fungsinya hanya sebagai pembawa keturunan. Fungsi ini sangat menentukan bagi perjalanan sejarah Aceh, karena konflik yang berlangsung selama berabad-abad telah mengorbankan jutaan jiwa masyarakat Aceh dan resistensi yang memuncak dari konflik-konflik tersebut adalah kebutuhan untuk mempertahankan eksistensi sebagai perempuan Aceh.

\section{Gender dan Ideologi Politik}

Gaya kepemimpinan perempuan Aceh merupakan peranan yang dilakukan dengan konsep ideologi syariat Islam. Perspektif keberadaan ideologi dalam politik kontemporer Aceh, terjadi banyak persoalan yang dihadapi perempuan Aceh ketika berhadapan dengan rezim bias gender dalam menerapkan syariat Islam yang telah diformalkan dalam qanun. Banyak qanun yang ternyata membuat aktifitas dan identitas perempuan terkendala oleh kebijakan yang dibuat oleh pemerintahanAceh. Masalah syariat Islam yang menjadi persoalan serius di pihak lain disebabkan banyak pemahaman tentang kebijakan termarjinalisasi keberadaan perempuan dari berbagai daerah Aceh, salah satu terjadi di Aceh Barat secara substansi dalam penerapan pemakaian busana muslim. Maka oleh sebab itu, eksisitensi gaya kepemimpinan perempuan di Aceh dipengaruhi oleh nilai asas syariat Islam dan menjadi kontradiksi bagai kalangan masyarakat dalam keterwakilan perempuan di jabatan publik. Namun secara filosofi keberadaan dan julukan perempuan secara kharismatik, raional mampu menjalankan organisasi dalam mengendalikan emosional yang sudah dijalan oleh pemerintah Acehketerwakilan perempuan sebagai gabernur Aceh, dan beberapa unsur partai politik yang lain. Maka gagasan gaya kepemimpinan perempuan Aceh adalah moralistik yang menjadi tantanan nilai budaya yang sangat tinggi dengan kedudukan perempuan Aceh sebagai unsur utama dalam pembangunan syariat Islam.

\section{Kesimpulan}

Gaya kepemimpinan perempuan Aceh adalah gaya kepemimpinan moralis. Gaya kepemimpinan ini gaya kepemimpinan yang paling menghargai bawahannya. Kepribadian pemimpin model ini adalah seorang pemimpin bergaya moralis sifatnya hangat dan sopan kepada semua orang. Pemimpin bergaya moralis pada dasarnya memiliki empati yang tinggi terhadap permasalahan para bawahannya. Kepemimpinan Perempuan Aceh dalam organisasi sangat signifikan dalam keterwakilan pengambilan keputusan organisasi. Keterwakilan juga memiliki fungsi strategis sebagai 
internalisasi komunikatif yang tegas dalam menanamkan nilai-nilai kesetaraan gender setiap aktivitas dan pola hubungan struktur, peran, dan fungsi sebuah sistem berada. Pola kepemimpinan organisasi dalam menjalankan tugas dan tanggungjawab sosial serta budaya dapat dilakukan melalui proses negosiasi dan gotong-royong yang di anutnya,dimana segala bentuk perbedaan dapat menemukan harmoninya dengan pembagian peran dan fungsi yang seimbang dari kedudukan dan komitmen sepenuhnya bagi perempuan Aceh dalam peningkatan pembangunan syariat Islam.

\section{Daftar Pustaka}

Ahmad. B.K (2015). Perempuan Aceh dalam Perspektif Sosiologi dan Antopologi, Gender Quality : Intenational Journal Of Child and Gender Studies. Vol. 1. No. 21. p. 37;

Hulwati. (2005). Memahami Kesetaraan Gender dalam Fiqh : Analisis Teori Evolusi Kontinuitas Fiqh. Jurnal Ilmiah Kajian Gender. Vol. 5. No. 1, P. 20;

Hartati. N. (2014). Kesetaraan dan Keadilan Gender dalamKeadilan Gender dalam Pandangan Perempuan Bali Studi Fenomenologis Terhadap Penulis Perempuan Bali. Jurnal Psikologi Undip. Vol. 13, No. 2. P. 149;

Jeumpa. N. (2016). Peran Perempuan Aceh Pada Pendidikan dan Politik. Jurnal Ilmiah Didantika. Vol. 16. No. 2.p. 154;

Puspitawati. H. (2010). Persepsi Peran Gender Terhadap Pekerjaan Domestik dalam Publik Pada Masahasiswa IPB. Jurnal Studi Gender. Vol. 1, No. 1. P. 34;

Lauler. H. R (1993). Perspektif Tentang Perubahan Sosial, Jakarta: Rineka Cipta;

Khalil. Z. (2013). Penguatan Pemberdayaan Perempuan dalam Perencanaan Musyawarah Rencana Pembangunan di Kota Banda Aceh. UMM;

Roviana. S. (2016). Indentitas Perempuan Aceh Pasca Pemberlakuan Syariat Islam: Sebuah Kajian Kepustakaan. Jurnal Ushluddin. Vol. 5. No.1. p. 83;

Sari. P. D. (2016). Persepsi Ulama tentang Keterlibatan Perempuan dalam Bidang Politik di Aceh Selatan. Al-Lubb. Vol.1. No. 1. P.144;

Saiful. T. (2016). Gender Perspektif Syariat Islam di Aceh. Jurnal Ilmu Hukum. Vol. 10. No. 2. P. 236;

Wahyuninggrouem. S. (2005). Peran Perempuan di Era Baru di Nanggro Aceh Darussalam. Antropologi Indonesia. Vol. 29. No.1. p. 94. 